Marina Goulart da Silva

(Dhtps://orcid org/0000-0001-5354-7948

Guilherme Cabreira Daros ${ }^{1}$

Ohttps://orid.org/0000-0001-7402-9154

Rafael Mariano de Bitencourt Ohttps://orcid.org/0000-0003-4694-3808

Betine Pinto Moehlecke Iser $^{1}$ Whttps://orcid.org/0000-0001-6061-254

\section{Psychiatric hospitalizations in Brazil: exploratory and trend analysis from 2009 to 2019}

\author{
Internações psiquiátricas no Brasil: análise exploratória \\ e de tendência de 2009 a 2019 \\ DOI: $10.1590 / 0047-2085000000303$
}

\begin{abstract}
Objective: To examine the rates of psychiatric hospitalization and the average length of stay, in Brazil, from 2009 to 2019, according to sociodemographic variables and character of the hospitalization (elective or urgency). Methods: This is an ecological study, with data collected from the Hospital Information System of the Unified Health System (SIH/SUS). Hospital admission rates were described according to diagnosis, sex, and age group. Percentage variation and rate ratios were calculated. To evaluate the time series, the data were submitted to linear regression analysis. Results: The rate of hospitalization for mental disorders decreased from 14.2/10,000 in 2009 to 11.2 in 2019, with the most significant variation occurring between mental and behavioral disorders due to alcohol use. The men had about twice as many episodes as the women in all the years evaluated. Higher rates were found in the age group of 30 and 59 years. The length of stay also decreased in the period. Besides, the urgency character presented almost $82 \%$ of the total hospitalizations. Conclusion: There was a reduction in hospital admissions for mental disorders in the analyzed period, demonstrating the relevance of mental health care changes resulting from the Psychiatric Reform.
\end{abstract}

KEYWORDS

Mental health, mental disorders, hospitalization.

\section{RESUMO}

Objetivo: Examinar as taxas de hospitalização psiquiátrica e o tempo médio dessas internações, no Sistema Único de Saúde (SUS) do Brasil, de 2009 a 2019, segundo variáveis sociodemográficas e caráter da internação (eletiva ou urgência). Métodos: Trata-se de um estudo ecológico, com dados coletados do Sistema de Informações Hospitalares (SIH/SUS). Foram descritas as taxas de internação hospitalar conforme diagnóstico, sexo e faixa etária. Calcularam-se a variação percentual e a razão das taxas. Para avaliação da série temporal, os dados foram submetidos à análise de regressão linear. Resultados: A taxa de internação hospitalar por transtornos mentais reduziu de 14,2/10.000 em 2009 para 11,2 em 2019, tendo a maior variação ocorrido entre os transtornos mentais e comportamentais devidos ao uso de álcool. O sexo masculino apresentou cerca de duas vezes mais episódios que o sexo feminino, em todos os anos avaliados. Maiores taxas foram verificadas na faixa etária de 30 e 59 anos. O tempo de internação também apresentou redução no período. Além disso, o caráter de urgência apresentou quase $82 \%$ do total de internações. Conclusões: Houve redução das internações hospitalares por transtornos mentais no período analisado, demonstrando a relevância das mudanças na assistência em saúde mental advindas da Reforma Psiquiátrica.

\section{PALAVRAS-CHAVE}

Saúde mental, transtornos mentais, hospitalização. 


\section{INTRODUCTION}

The need for mental health care changes began to be debated in Europe in the 1960s, but it was only in the 1980s that psychiatric reform began to be constituted in Brazil'. This reform aimed to reintegrate the individual affected by mental disorders, the restructuring of all mental health services, the focus on primary care - especially with the emergence of Psychosocial Care Centers (CAPS) - and the creation of new substitute devices for psychiatric hospitalization ${ }^{2,3}$. As of 2001, with the enactment of Law no 10.216 - which has provisions for the protection and rights of people with mental disorders and the redirection of the mental health care model - Brazil then entered the group of countries that have modern legislation and consistent with the guidelines of the World Health Organization.

In 2004, reducing the number of beds in psychiatric hospitals and the deinstitutionalization of people with a long history of hospitalization were deepened through the Annual Program for Restructuring Hospital Care in the Unified Health System (PRH), leading to a progressive reduction in hospital size. The process was planned, with a rhythm agreed between city and state managers, hospitals, and social control ${ }^{4}$. The Return Home Program, in turn, is one of the main instruments in the psychosocial rehabilitation process, contributing to the social insertion process of people with a long history of hospitalization in these hospitals, through the monthly payment of rehabilitation assistance and a network mental health care capable of meeting the individual's demands's.

In the popular imagination, psychiatric hospitalization remains a device reserved for the imprisonment of madness; however, it remains a widely used resource ${ }^{5}$. There are also many clinical situations in which hospitalization - not only in psychiatric hospitals but also in general hospitals - is prudent, and may even be mandatory, especially for the most severe cases such as in situations in which there is a mental disorder with a risk of social exposure. Thus, the purpose of hospitalization focuses on stabilizing the patient, reevaluating pharmacological treatment (or instituting it), and raising psychosocial needs, aiming at the patient's social reintegration ${ }^{6}$.

Therefore, in order to understand the consequences of psychiatric reform, the objective of this study was to describe the rates of psychiatric hospitalization and the average length of hospital stay, in the Unified Health System in Brazil (SUS), from 2009 to 2019, according to the main characteristics of patients.

\section{METHODS}

This is an ecological time series study describing the rates of hospitalizations for mental and behavioral disorders (chapter $V$ of ICD-10) and the average number of days of hospitalization, in individuals of both sexes, in Brazil, from 2009 to 2019. These data were collected according to the following items from the list of morbidities: mental and behavioral disorders due to alcohol use (F10 to F109), mental and behavioral disorders due to the use of other psychoactive substances (F11 to F19), schizophrenia, schizotypal and delusional disorders (F20 to F29), mood disorders (affective) (F30 to F39), neurotic disorders, related to stress and somatoform disorders (F40 to F48), mental retardation (F70 to F79), other mental and behavioral disorders (F00 to F09, F50 to F69 and F80 to F99).

For hospital morbidity data related to Health Unified System, the data source used was the Hospital Information System (SIH/SUS) available from the Datasus Tabnet. For the population data needed to calculate hospitalization rates, the population residing in Brazil and regions was used, through the Census (for data until the year 2012), and for later years, the population estimated for Federation Units, by sex and age groups: 2000-2030.

The spreadsheets were prepared using Microsoft Excel ${ }^{\circ}$ software and analyzed using the Stata 12.0 program based on the extracted data. The rates were calculated, according to the study variables, using the formula:

Number of hospitalizations according to psychiatric morbidity in the year The total population in the year $\times 10,000$ inhabitants

The percentage change was calculated using the formula:

$$
\left(\frac{\text { Final rate }- \text { initial rate }}{\text { Inicial rate }}\right) \times 100
$$

The rate ratio was also calculated for dichotomous variables. For evaluating the period's time series, linear regression analysis was used, with the coefficient of determination of the series $\left(R^{2}\right)$ being presented, the average annual variation of the series values, given by the coefficient $\beta$. The response variable $\left(\mathrm{Yi}_{\mathrm{i}}\right)$ was the hospitalization rate for mental disorders, and the explanatory variable (Xi) was the year of hospitalization. The positive/negative slope value ( $\beta$ ) represents the average annual increase/decrease in hospitalizations for each year analyzed. Values of $p<0.05$ were considered significant.

This study does not need to be evaluated by the Research Ethics Committee (CEP), due to the use of only secondary data available in different open/public health information systems, with no need to access nominal data to identify cases. The data were used in an aggregate manner. The authors declare there is no conflict of interest.

\section{RESULTS}

The hospitalization rate for mental disorders was 14.2 admissions per 10,000 residents in 2009 and 11.1 in 2019, 
representing a 22\% reduction in the period, with an average variation of 0.5 percentage points (p.p.) per year. The highest percentage variation occurred for mental and behavioral disorders due to alcohol use (-42\%), followed by Schizophrenia and schizotypal and delusional disorders (-34.5\%). The most significant annual reduction, of -0.23 p.p./ year, was verified for schizophrenia hospitalizations. The only condition that did not show a trend to decrease was mood disorders [affective], going from 2.5 to 2.8 hospitalizations for every 10,000 residents (Figure 1).

The length of stay also decreased by $50 \%$ in the period, from an average of 40 to 20 days. The disorder with the most extended average hospital stay was mental retardation, but also the one with the second most significant reduction (average of 104 days in 2009, and 30 days in 2019), behind only the group of other mental and behavioral disorders (-77, 56\%) (Figure 2).

The hospitalization rates for mental and behavioral disorders are about twice as high for men in all the years evaluated. The reduction in the number of men hospitalizations was $28.02 \%$ or 0.75 p.p./year, while for women, it was $10.55 \%$, or 0.24 p.p./year, both significant (Table 1).

Regarding the age of the hospitalized patients, the group belonging to the range between 30 and 59 years old had the highest hospitalization rate over the years, followed by patients aged 15 to 29 years. There was a trend to reduced hospitalization rates from 15 years of age onwards, with the most considerable reduction in the 30-59-year-old group, being 1.24 pp per year. Children under 15 years old already had lower hospitalization rates, and the reduction was not significant (Table 1).

The urgency character represented $81.89 \%$ of the total admissions between 2009 and 2019. The rates ratio went from 3.3 in 2009 to 6.9 in 2019 due to the increase in the proportion of urgency admissions and reduced elective hospitalizations. However, both rates of hospitalization in the period tended to decrease, to a greater extent for emergency care (-0.28 p.p./year) (Table 1).

The rate of hospitalization for mental and behavioral disorders was higher in the South Region of Brazil, with 25.6 hospitalizations per 10,000 inhabitants in 2009 and 25.10 in 2019, with a stable trend. The North region was the only one that showed an increase in hospitalizations for mental and behavioral disorders in the period, from 3.43 to 4.16 hospitalizations for every 10,000 residents. The others showed a downward trend (Table 1).

\section{DISCUSSION}

The first studies on the prevalence of psychiatric disorders in primary health care were carried out in the 1960s by Shepherd et al. (1984). As countries began to give primary care importance as a strategy for organizing health services, studies on mental health-related to primary health care are increasingly present in the scientific community ${ }^{7}$.

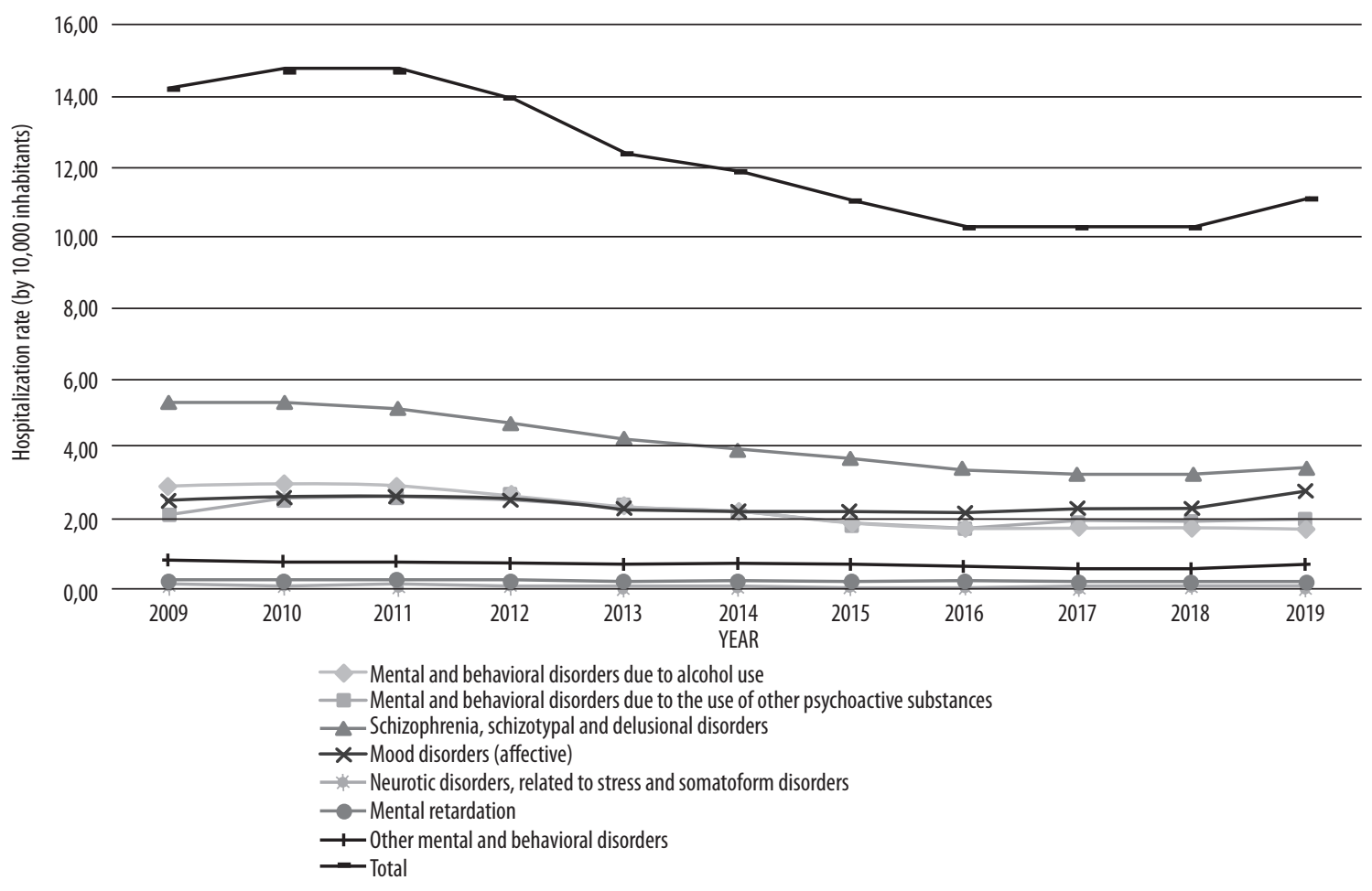

Figure 1. Hospitalization rate according morbidities by year, Brazil, 2009-2019. 


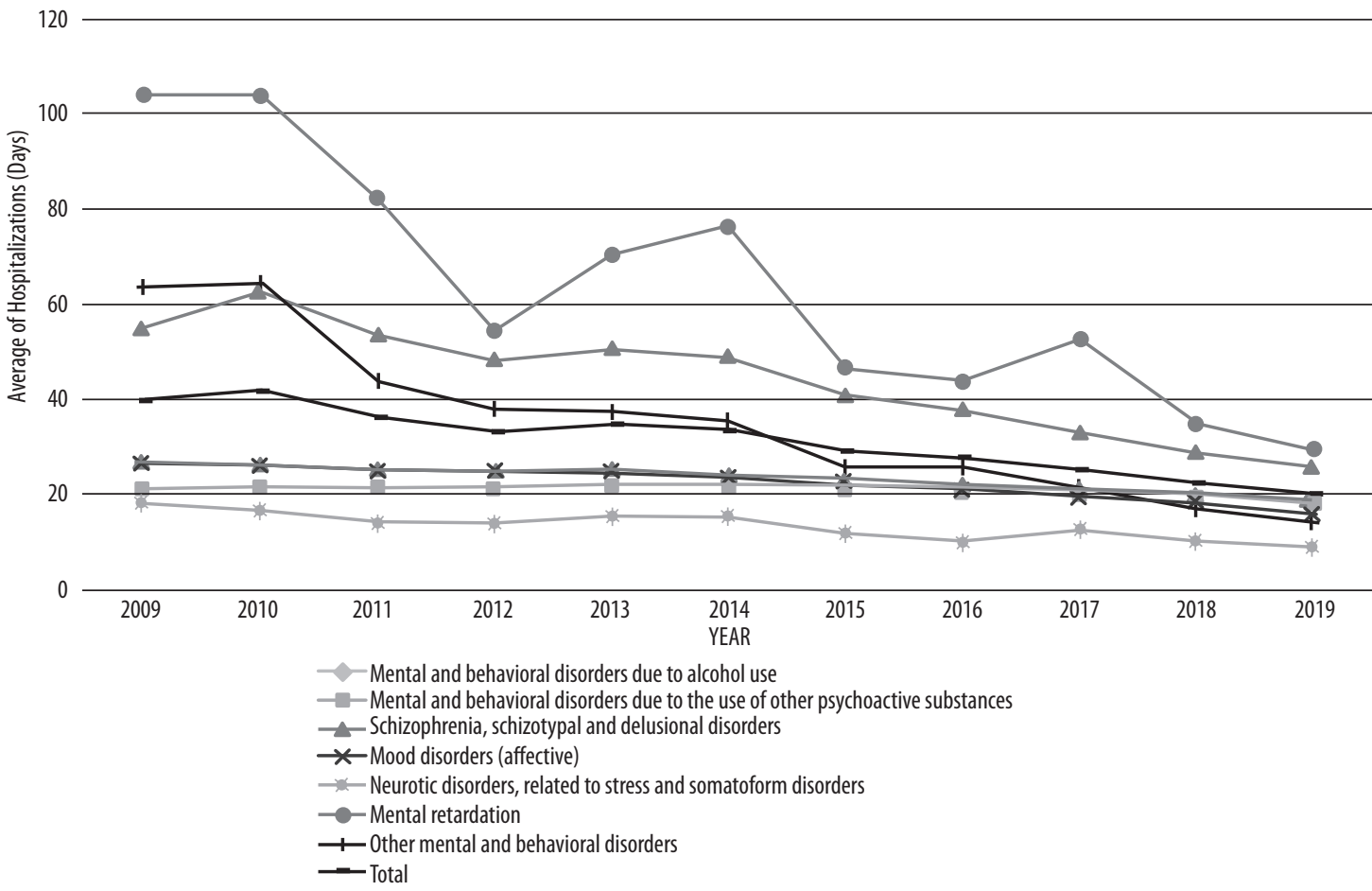

Figure 2. Average days of hospitalization according morbidities by year, Brazil, 2009-2019.

Table 1. The hospital admission rates for mental and behavioral disorders from 2009 to 2019 in Brazil, per 10,000 inhabitants, according to sociodemographic variables and character of hospitalization

\begin{tabular}{|c|c|c|c|c|c|c|c|c|c|c|c|c|c|c|}
\hline & 2009 & 2010 & 2011 & 2012 & 2013 & 2014 & 2015 & 2016 & 2017 & 2018 & 2019 & $\begin{array}{c}\text { Average } \\
\text { annual } \\
\text { variation }^{\#}\end{array}$ & $\mathrm{p}$-value & $\mathbf{R}^{2}$ \\
\hline \multicolumn{15}{|l|}{ Sex } \\
\hline Male & 18,76 & 19,63 & 19,46 & 18,38 & 16,14 & 15,37 & 14,21 & 13,17 & 13,01 & 13,33 & 13,50 & $-0,76$ & $<0,001$ & 0,85 \\
\hline Female & 9,79 & 10,13 & 10,26 & 9,73 & 8,72 & 8,48 & 7,99 & 7,59 & 7,65 & 8,05 & 8,76 & $-0,24$ & 0,0031 & 0,60 \\
\hline \multicolumn{15}{|c|}{ Age range (years) } \\
\hline$<15$ & 0,39 & 0,70 & 0,89 & 0,87 & 0,77 & 0,75 & 0,75 & 0,79 & 0,67 & 0,81 & 0,15 & $-0,02$ & 0,52 & 0,06 \\
\hline $15-29$ & 14,00 & 14,69 & 14,44 & 13,70 & 12,59 & 11,81 & 10,88 & 10,63 & 10,95 & 11,78 & 13,81 & $-0,28$ & 0,045 & 0,30 \\
\hline $30-59$ & 25,38 & 25,36 & 25,30 & 23,88 & 20,64 & 19,75 & 18,18 & 16,5 & 12,31 & 16,40 & 16,48 & $-2,24$ & $<0,001$ & 0,82 \\
\hline$\geq 60$ & 8,77 & 8,99 & 9,26 & 8,76 & 9,02 & 7,84 & 7,17 & 6,92 & 6,96 & 6,94 & 7,08 & $-0,26$ & $<0,001$ & 0,82 \\
\hline \multicolumn{15}{|c|}{ Internment character } \\
\hline Elective & 3,27 & 3,30 & 3,18 & 2,60 & 2,21 & 2,07 & 1,93 & 1,68 & 1,47 & 1,52 & 1,41 & $-0,21$ & $<0,001$ & 0,93 \\
\hline Urgency & 10,93 & 11,48 & 11,59 & 11,36 & 10,17 & 9,82 & 9,13 & 8,66 & 8,83 & 9,13 & 9,69 & $-27,6$ & 0,002 & 0,68 \\
\hline \multicolumn{15}{|l|}{ Region } \\
\hline North & 3,43 & 3,88 & 4,09 & 3,92 & 3,65 & 4,41 & 4,20 & 4,24 & 4,15 & 4,39 & 4,16 & 0,06 & 0,016 & 0,49 \\
\hline Northeast & 10,73 & 10,72 & 10,10 & 9,46 & 8,09 & 7,83 & 7,11 & 6,65 & 6,38 & 6,55 & 6,90 & $-0,49$ & $<0,001$ & 0,89 \\
\hline Southeast & 14,28 & 14,76 & 14,82 & 13,76 & 12,15 & 11,47 & 10,38 & 9,33 & 9,13 & 9,53 & 10,44 & $-0,62$ & $<0,001$ & 0,83 \\
\hline South & 25,58 & 28,05 & 28,47 & 27,54 & 23,37 & 24,92 & 23,97 & 23,71 & 24,68 & 25,37 & 25,10 & $-0,22$ & 0,600 & 0,03 \\
\hline Midwest & 16,27 & 16,70 & 17,49 & 17,28 & 14,64 & 12,74 & 12,68 & 11,13 & 10,85 & 11,20 & 11,56 & $-0,30$ & 0,038 & 0,40 \\
\hline Brazil & 14,20 & 14,78 & 14,77 & 13,97 & 12,39 & 11,88 & 11,06 & 10,34 & 10,30 & 10,30 & 11,10 & $-0,50$ & $<0,001$ & 0,81 \\
\hline
\end{tabular}

"Average annual variation, in percentage points per year, referring to the $B$ coefficient of linear regression. 
It is estimated that $30 \%$ of adults worldwide meet the diagnostic criteria for any mental disorder, with around 80\% of these living in low and middle-income countries, such as Brazil ${ }^{8}$. Worldwide, mental disorders account for $32.4 \%$ of the years of life lived with disability ${ }^{9}$, and, in Brazil, it is estimated that depressive and anxious disorders account for the fifth and sixth causes, respectively, of years of life lived with disability ${ }^{10}$.

Psychiatric hospitalization has the objective centered on stabilizing the patient, minimizing risks by assessing psychosocial needs, medication adjustment, and social reintegration of the patient in his environment ${ }^{11}$. The data analyzed in the present study demonstrate a trend to decrease hospitalizations for mental and behavioral disorders between 2009 and 2019. Among patients who, in some situations, may have an indication for psychiatric hospitalization, there are patients diagnosed with schizophrenia'2, which corroborates the finding of this study, which shows schizophrenia and schizotypic and delusional disorders as the main reason for hospitalization over the years. Schizophrenia is a complex syndrome, considered by some authors as the most severe psychiatric disorder, and can damage patients and their families' lives, usually causing significant impacts on their daily lives ${ }^{12}$. However, these were also the disorders that suffered the most significant annual reduction, although we have not found justifications for this finding in the literature.

Schizophrenia also has an average age of hospitalizations close to 40 years ${ }^{12-14}$, and like bipolar disorder, it is a chronic and progressive disease. This, coupled with the fact that some disorders - such as depressive disorders - peak at 30 years of age ${ }^{15}$, can explain the 30-59 age group as having the highest hospitalization rate.

Regarding hospital stay, mental retardation was the disorder with the highest average number of days in the hospital (54.5 days), which may be related to some factors, such as self-aggressive behavior - a problem that is particularly common in the population with mental retardation ${ }^{16}$ - and the difficulty of accepting this individual in the family and social sphere from a significant stigma concerning these diseases. However, in general, there was a decrease in hospitalization time, possibly related to the psychiatric reform process, which aimed at the reintegration of the individual affected by mental disorders, through the creation of CAPS and some specific actions, such as the Back Home Program. Researchers had already pointed out a relationship between the reduction in the number of hospitalizations in some regions of the country and the increase in the coverage of Primary Care and CAPS ${ }^{17}$. Besides that, the number of elective admissions is minimal, compared to $81.9 \%$ of emergency admissions, which may also be related to the new way of facing psychiatric illnesses due to the changes resulting from the reform started in 2001. Epidemiological studies have shown differences in the incidence, prevalence, and the course of mental and behavioral disorders according to sex. These studies indicate that women have a higher prevalence of anxiety and mood disorders. In comparison, men have a higher prevalence of disorders associated with the use of psychoactive substances, antisocial and schizotypal personality disorders, impulse control disorders, and attention deficit hyperactivity disorder, both in childhood and in adulthood ${ }^{18,19}$. Such results may be linked to the male hospitalization rate being almost twice as high as that of the female sex since three of the four disorders with the highest hospitalization rate found here are linked to a higher prevalence in men.

According to the World Health Organization, about $10 \%$ of the populations from urban centers worldwide - including the Brazilian territory - abuse psychoactive substances, regardless of age, sex, education level, and purchasing power ${ }^{20}$. However, it was found that the highest percentage variation occurred in mental and behavioral disorders resulting from alcohol use, with a decrease of $42 \%$, which can be explained by the total alcohol consumption per person in Brazil having suffered a drop of 8.8 to 7.8 liters per year, between the years 2010 and $2016^{21}$. However, it is still necessary to continue the measures to prevent alcohol consumption adopted in recent years, considering that the Brazilian population's average consumption remains higher than the world average (6.4 liters per year ${ }^{21}$ ).

When addressing data by region of the country, a higher rate of hospitalizations was found for the South Region and lower in the North. About the variation of these rates over the years, the Northeast region showed a more significant decrease. However, it was not possible to establish a cause for this finding through the literature. The possibility of further investigation on mental health in each region of the country is suggested, covering in addition to the number of hospitalizations, the number of available beds, and the extension of the health care network, such as the one already carried out in São Paulo and Rio de Janeiro, in the Southeast region ${ }^{17}$.

Among the possible limitations, the lack of access to data from private institutions stands out. As some compulsory hospitalizations are sent to private institutions due to the limited number of places available in the Unified Health System, and, as we do not have access to these data, we cannot rule out possible interferences in the results found. It is important to emphasize that, although psychiatric disorders usually require an extended hospital stay, the hospitalization authorizations (AlH) have defined time; so, in long-term hospitalizations, the same patient can have multiple AlHs. Thus, the hospitalization rates presented here cannot be interpreted as incidence rates. 


\section{CONCLUSION}

Mental disorders involve not only the health sector but also several sectors of society - education, employment, justice, social assistance, and others -, which requires a joint effort between the State, associations of people with mental disorders, family and civil society, in favor of the development of specific guidelines and health services in this area22.

Finally, it is concluded that there was a reduction in hospitalizations during the study period in most mental disorders, mainly in the population between 30 and 59 years old, showing relevance in the adoption of measures for the reintegration of individuals affected by these disorders and the restructuring of health services.

\section{INDIVIDUAL CONTRIBUTIONS}

Marina Goulart da Silva - Contributed to the study conception and design, data analysis and interpretation, writing and review of the manuscript, and the final approval of the version to be published.

Guilherme Cabreira Daros - Contributed to the study conception and design, data analysis and interpretation, writing, and review of the manuscript, and the final approval of the version to be published.

Rafael Mariano de Bitencourt - Contributed to the study conception and design, data analysis and interpretation, writing, and review of the of the manuscript, and the final approval of the version to be published.

Betine Pinto Moehlecke Iser - Contributed to the study conception and design, data analysis and interpretation, writing and review of the of the manuscript, and the final approval of the version to be published.

\section{CONFLICT OF INTERESTS}

The authors declare that there is no conflict of interests.

\section{REFERENCES}

1. Borges CF, Baptista TWDF. 0 modelo assistencial em saúde mental no Brasil: a trajetória da construção política de 1990 a 2004. Cad Saúde Pública. 2008;24(2):456-68.
2. Barros REM, Tung TC, Mari JDJ. Serviços de emergência psiquiátrica e suas relações com a rede de saúde mental brasileira. Rev Bras Psiquiatr. 2010;32(Suppl 2):S71-7.

3. Silva TL da, Maftum MA, Kalinke LP, Mantovani M de F, Mathias TA de F, Capistrano FC. Profile of hospitalizations in the psychiatric unit of a general hospital. REME Rev Min Enferm. 2014;18(3):644-59.

4. Brasil. Ministério da Saúde. Secretaria de Atenção à Saúde. DAPE. Reforma Psiquiátrica e Política de Saúde Mental no Brasil. In: Conferência Regional de Reforma dos Serviços de Saúde Mnetal: 15 anos depois de Caracas. Brasília; 2005. p. 56.

5. Horta RL, Costa JSD da, Balbinot AD, Watte G, Teixeira VA, Poletto S. Hospitalizações psiquiátricas no Rio Grande do Sul de 2000 a 2011. Rev Bras Epidemiol. 2015;18(4):918-29.

6. Brasil. Ministério da Saúde. Secretaria-Executiva. Secretaria de Atenção à Saúde. Legislação em Saúde Mental: 1990-2004. 5ª ed. Brasília: Ministério da Saúde; 2004. 340p.

7. Pereira ADA, Vianna PC de M. Saúde mental. Belo Horizonte: Coopmed; 2009. 80p.

8. Steel Z, Marnane C, Iranpour C, Chey T, Jackson JW, Patel V, et al. The global prevalence of common mental disorders: a systematic review and meta-analysis 1980-2013. Int J Epidemiol. 2014;43(2):476-93.

9. Vigo D, Thornicroft G, Atun R. Estimating the true global burden of mental illness. Lancet Psychiatry. 2016;3(2):171-8.

10. Marinho F, de Azeredo Passos VM, Carvalho Malta D, Barboza França E, Abreu DMX, Araújo VEM, et al. Burden of disease in Brazil, 1990-2016: a systematic subnational analysis for the Global Burden of Disease Study 2016. Lancet. 2018;392(10149):760-75.

11. Cardoso L, Galera SAF. Internação psiquiátrica e a manutenção do tratamento extrahospitalar. Rev Esc Enferm USP. 2011;45(1):87-94.

12. Santana AFFDA, Chianca TCM, Cardoso CS. Qualidade de vida de pacientes com esquizofrenia internados em hospital de custódia. J Bras Psiquiatr. 2009;58(3):187-94.

13. Crepalde $R$ dos $S$, Santos AS, Rodrigues LS de M, Volpe FM, Brandão CMR. Perfil epidemiológico de portadores de esquizofrenia internados no Instituto Raul Soares. Rev Méd Minas Gerais. 2016;26(Supl 5):102-9.

14. Ferreira AADA, Sena GS de, Galvão MVM, Felix RHDM, Mendonça RM, Guerra GCB, et al. Tendência temporal da esquizofrenia: um estudo realizado no âmbito hospitalar. J Bras Psiquiatr. 2007;56(3):157-61.

15. Rakofsky J, Rapaport M. Mood Disorders. Contin Lifelong Learn Neurol. 2018;24(3):804-27.

16. Symons FJ, Clark RD, Hatton DD, Skinner M, Bailey DB. Self-injurious behavior in young boys with fragile X syndrome. Am J Med Genet. 2003;118A(2):115-21.

17. Miliauskas $C R$, Faus DP, Junkes $L$, Rodrigues RB, Junger W. Associação entre internações psiquiátricas, cobertura de CAPS e atenção básica em regiões metropolitanas do RJ e SP, Brasil. Ciênc Saúde Coletiva. 2019;24(5):1935-44.

18. Andrade LHSG de, Viana MC, Silveira CM. Epidemiologia dos transtornos psiquiátricos na mulher. Rev Psiquiatr Clín. 2006;33(2):43-54.

19. Miranda CA de, Tarasconi CV, Scortegagna SA. Estudo epidêmico dos transtornos mentais. Aval Psicol. 2008;7(2):249-57.

20. Brasil. Ministério da Saúde. Secretaria Executiva. Coordenação Nacional de DST/AIDS. A política do Ministério da Saúde para a atenção integral a usuários de álcool e outras drogas. Brasilia; 2003. 60p.

21. World Health Organization. Global status report on alcohol and health 2018. Geneva: WHO; 2018. 472p

22. World Health Organization. Mental health, policy, plans and programmes [Internet]. Mental Health Policy and Service Guidance Package. Geneva: WHO; 2005 [cited 2020 Jun 5]. 122p. Available from: https://www.who.int/mental_health/policy/services/ essentialpackage1v1/en/ 